\title{
Think Pair Share Technique to Promote Students' Reading Comprehension
}

\author{
Retno Dwigustini ${ }^{1} *$ dan Jenika Widiya ${ }^{2}$ \\ ${ }^{1}$ Program Studi Pendidikan Bahasa Inggris, STKIP Kusuma Negara, Indonesia \\ ${ }^{2}$ Program Studi Sastra Inggris, Universitas Bina Sarana Informatika, Indonesia \\ *retnodwigustini72@gmail.com
}

\begin{abstract}
The objective of the research is to promote students' reading comprehension through Think Pair Share technique. The present research employed qualitative approach with Classroom Action Research (CAR) method. The participants involved were one class of seventh graders consisting of 22 students. The research was conducted in three cycles. Observation, test and interview were used to collect the data. The result revealed that 1) students' score of reading comprehension increases after the implementation of Think Pair Share technique (in cycle I, only 36\% students passed the passing grade, in cycle II $73 \%$ of them passed the passing grade, and in cycle III, $100 \%$ students passed the passing grade; and 2) students' motivation and learning excitement improve. The findings lead to a conclusion that this technique can promote students' reading comprehension. It is then recommended for English teachers to keep using this technique as a solution to assist them in teaching reading comprehension and to motivate their students to be more active in learning.
\end{abstract}

Keywords: reading comprehension, think pair share technique.

Dikirim: 29 May 2020

Direvisi: 27 June 2020

Diterima: 28 June 2020

Identitas Artikel:

Dwigustini, R., \& Widiya, J. (2020). Think Pair Share Technique to Promote Students' Reading Comprehension. Jurnal Ilmu Pendidikan (JIP) STKIP Kusuma Negara, 12(1), 25-34.

\section{INTRODUCTION}

Reading comprehension plays substantial roles either in students' academic life, personal or professional in the future. In academic life, reading comprehension shall lead students to have excellent academic achievement (Anggraini, 2017). Personally, reading comprehension, for example in reading for pleasure, is needed to fulfill the function of social engagement and personal development (Howard, 2011). In the future, professional field also requires excellent reading comprehension as a part of workplace readiness standard skill (ACT, 2013).

In fact, reading comprehension remains as challenging and demanding learning activity for students. At a private junior high school in Bekasi West Java, it is found out that most students find difficulties in comprehending text due to the following problems. Vocabulary knowledge remains as the big problem for the students. Additionally, decoding seems to be another issue faced by the students. These two problems have been either highlighted by Graham \& Bellert (2005) as common problems faced by students in reading comprehension. At that school, motivation and learning excitement become a hindrance for the students as well.

One technique proposed to enhance students reading comprehension is Think Pair Share. This technique has been being believed to provide chance for students 
to improve their motivation and understanding of text (Ageasta \& Oktavia, 2018). Palupi, Suparman \& Suka (2013) claimed that this technique is effective in enhancing students' reading comprehension. Statistically, Supriyani, Sudirman \& Mahpul (2017) and Suryani \& Rifa'at (2019) have proved that this technique gives significant difference on students' reading comprehension. More importantly, Maulida (2017) acknowledged that this technique gives assistance for teachers to teach reading comprehension to their students.

Considering the explication above, the present research aims at finding out how Think Pair Share can assist and enhance students' reading comprehension and motivation, and how the students' perceive the technique implementation in their classroom.

\section{THEORETICAL FRAMEWORK \\ Reading Comprehension}

Reading comprehension is the process of interacting and constructing meaning from the text by readers. Readers must comprehend about the text that they read. So, they will get new knowledge from the text or passage. According to Nunan (2003) Reading is activity that used background knowledge to understand the message being conveyed by the text in order to expand the meaning. The primary goal of reading is comprehension, which according to Coiro (2003) is the process of simultaneously extracting and constructing meaning through interaction and involvement with written language. It means that comprehension is not a passive process, but an active one. The reader actively engages with the text to construct the meaning. This active engagement includes making use of prior knowledge. Reading Comprehension is an interesting activity in teaching and learning process, and it is one of the four basic skills that have to be learned by the students. But commonly, it is a boring one. The students usually seem to be lazy and do not enjoy this activity; one reason is because the teacher is being monotonous in teaching reading comprehension.

According to Patel \& Jain (2008), there are some types of reading. They are intensive reading, extensive reading, reading aloud and silent reading. Intensive reading is used on shorter texts in order to extract specific information. Brown (2001) stated that Extensive reading is carried out to achieve a general understanding of usually somewhat longer text (book, longer article, or essay, etc.). Extensive reading is used to obtain a general understanding of a subject and includes reading longer texts for pleasure, as well as business books. Reading aloud involves students in reading for enjoyments and provides demonstration of fluent reading. Silent reading is useful to make reader more concentrate to comprehend the meaning of the text. Harmer (2007) stated the reading activity focuses to learn composition of the text which is the variants of the text depends on the purpose of the reader.

Assessment is measurement done by teacher to know how far the students have already understood the materials that has been discussed. In teaching reading, assessment is aimed to measure how far the students comprehend texts. Brown (2004) stated that assessment is a popular and sometimes misunderstood term in current educational practice. It means, any teacher only assess the students learning without tells their mistakes. Teachers just need a result like value from 
students. Finally, the students do not get anything from teaching and learning.

Besides that, there are some techniques that can be used by teachers to assess the reading comprehension of the students. Heaton (1975) stated that several ways of testing reading comprehension are treated in the following: matching tests, picture and sentence matching, true or false reading tests, multiple-choice tests, completion items, rearrangement items, cloze procedure, open-ended and miscellaneous items, cursory reading. Those ways can be used depends on the purposes and condition. The tests can be made for virtual tests or paper tests.

\section{Think Pair Share Technique}

Think Pair Share technique is a part of cooperative learning discussion. It is a simple technique, but very useful for teaching and learning process which developed by Frank Lyman of the University of Maryland. The people can practice think pair share technique everyday especially in teaching and learning process. This technique is easy to use by students. Himmele \& Himmele (2011) stated that think pair share is an easy total participation technique that you can start implementing every day. Theo, think pair share is a simple but powerful tool that should be used repeatedly and consistently throughout day. It means use prompts that require students to analyze the various points of view or the components that are inherent in your standard target. Ask questions that require students to explain how these components fit together or affect one another.

Arends (2009) stated that the think pair share has some steps should be followed by the teacher such as follows:

Step 1: Thinking, the teacher poses a question or an issue associated with the lesson and asks students to spend a minute time thinking alone about the answer or the issue. Students need to be taught that talking is not part of thinking time.

Step 2: Pairing, next, the teacher asks students to pair with their friends. Then, discuss what they have been thinking about. Interaction during this period can be sharing answer if a question has been posed or sharing ideas if a specific issue was identified. Usually, teacher allows no more than four or five minutes for pairing.

Step 3: Sharing, in the final step, the teachers asks the pairs to share what they have been talking about with the whole class. It is effective to simply go around the room from pair to pair and continue until about a fourth or half of the pairs have had a chance to report.

Think Pair Share Technique is effective in English learning especially to improve students reading comprehension. In this technique students think individually, cooperate with their pairs/group, and share with classmate. It will make students learn in teamwork. In teaching and learning process of reading, the Think Pair Share technique can arouse students' involvement. It encourages the students to be actively involved in classroom activities. It creates a learning atmosphere which is full of encouragement and positive relation among the group as well.

Kagan \& Kagan (2009) mentions some benefits of Think-Pair-Share technique. When students have appropriate think time, the quality of their response is improved. Students are actively engaged in thinking and thinking becomes more focused when it is discussed with a partner. 


\section{RESEARCH METHODOLOGY}

This study aims to improve students' reading comprehension at seventh grade students. This research is held at Aqidah Islamic Junior High School Cikarang Utara, Bekasi, West Java Indonesia. This research is conducted for 3 cycles. Research methodology is qualitative research used classroom action research. The steps of the research focus on teaching and learning process using classroom action research through Cycle I, Cycle II, Cycle III. Each cycle contains 4 steps consist of: Planning, Acting, Observing and Reflecting. The researchers choose class VII as the subject of the research that there are 22 students in the classroom consist of 13 male and 9 female students. The data were collected through observation, interviews and post-test. Based on the interviewing of the students on the pre-observation, most of the students like English but the students said they get difficulty in understanding of reading text. They can not comprehend what they read because they lack of vocabulary, lack of motivation, less attention to the teaching and do not active in learning English. Most of the students think that reading comprehension is considered to be hard for them. They just feel reading comprehension has so many traps and it has so many difficult words to understand.

\section{FINDINGS AND DISCUSSION}

\section{Findings}

The researchers found that many students lack ofinterest in reading. Basically the students can read if the researchers ask them to read the text. But many of them can't comprehend the reading text or do not understand the meaning of the text. Then, most of the students are not really interested in learning English. They often think that English is not their mother tongue so that they do not have to be really seriously to learn English.

To attract the students interest in reading and solve the problem in the class, the researchers use Think Pair Share technique in teaching and learning process. So that it is clear, the description of the subject of research must be from the aspect of school and the students themselves.

This research conducted for 3 cycles. It has some steps of teaching reading, they are:

1. Pre-teaching activity

The teacher comes to the class and greets the students in order to open conversation with the students. Then checking the studentse attendance list and looking at class environment. Next, the teacher gives paper about descriptive text and asks the students to guess the topic that will be taught. The teacher motivates the students by telling the learning objectives and basic competence that should achieve at the end of the lesson. Then the teacher actives the students' existing knowledge based on the topic that will be taught and ask some questions relating to the topic.

2. Whilst-teaching activity

In this phase, the teacher leads the students to the main activity in the teaching learning process and also applies the think-pair-share technique. The teacher guides the students by giving an example of descriptive text to the students. In 
reading descriptive text by using think-pair-share technique, there are several steps in whilst teaching: observing, questioning, experimenting, associating and communicating. In observing, the teacher shows the descriptive text for the students as the teaching material. Then the teacher asks students to read the text individually in order to get information from the text/passage. The students read the text silently. In questioning, the learning activity in this phase is the teacher asks questions about information that is not understood from the text or questions to obtain additional information. For example, the students may ask about unfamiliar words. In the exploring, the teacher and students discuss about the social function, the structure of the text, language feature and moral value as well as descriptive text. The teacher helps the students to answer the questions below the text and discuss it together. In the associating, the teacher gives the descriptive text for the students as an exercise. Then, the teacher asks the students to read the text again individually in order to get information from the text/passage. After reading the text, the teacher asks the students to answer the questions below the text. At this stage think-pair-share technique will be conducted. The teacher gives the students several times "wait time" to help the students review their background knowledge that is related to the topic given. This is known as "think' phase. After answering the questions, the teacher divides the students randomly into pairs (pair" phase) in order to avoid the gap between high and low students. The teacher asks the students to discuss the questions from the text with the partners. Each pair should think and discuss each other. At this point, the students ask their partners answer about questions from the text. The students share their own answer; this is known as share phase. They can find their ideas or change it during the discussion. In the communicating, when the students finished the discussion, the teacher calls on the students randomly and asks them to share their answer in front of the class. The students convey their answer. If their answer is wrong, the teacher will ask other students for the right answer. Finally, after the students answer all questions, the teacher explains the material completely and discuss with all of the students.

3. Post-teaching activity

The teacher gives a chance for the students to ask questions if they still do not understand about the material yet. The teacher may give feedback. Then teacher also asks students to conclude the lesson that has been learned together and asks the students to submit their task. The last one, teacher gives homework for the students to see the students understanding about what they have learned before.

The research result through reading test and document study show that there is an improvement in performed students, that the students can achieve $100 \%$ in the learning activities through think pair share technique. Because in cycle one, it is about 8 students of 22 or $36 \%$ could reach 70 of the standard minimum achievement. While 14 students of 22 or $64 \%$ fail.

Based on the result of cycle one above, it can be seen in Figure 1 that 8 students of 22 or $36 \%$ could reach 70 of the standard minimum achievement. While 14 students of 22 or $64 \%$ fail. It means they could not reach 70 of the standard minimum achievement. Percentage of the students' passing in cycle one.

$$
\text { Percentage }=\frac{F}{N} \times 100 \% \rightarrow P=\frac{8}{22} \times 100 \%=36 \%
$$




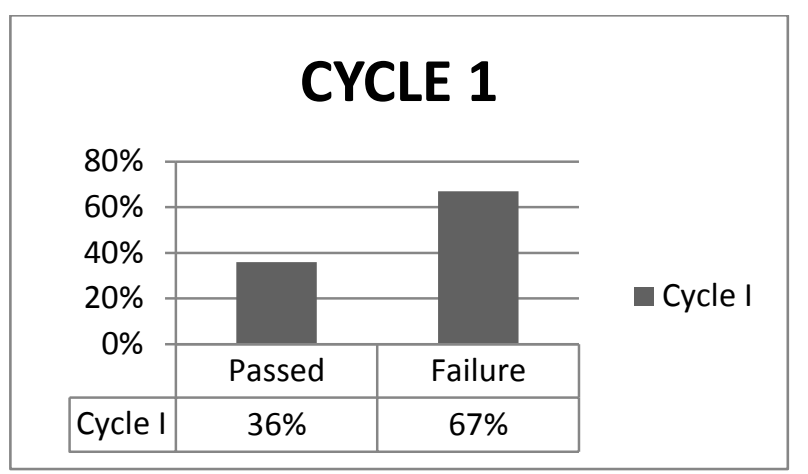

Figure 1. The Result of Students' Score in Cycle 1

Based on the Standard Minimum Achievement

In this cycle, the researchers make reflecting on the activities have been done. The reflecting included the situation of the class, the interest of the students' reading comprehension, the process of teaching learning through think pair share technique, students' motivation, spirit and also the way how to reduce the weakness of the action research and the result of the reading test. The researchers found that the students still find the difficult with fair score. Therefore, the researcher will continue this research to cycle two, because most of the students' score are still under standard of minimum score.

In cycle 2, the students can improve their reading comprehension in the cycle two that 16 students of 22 or $73 \%$ could reach 70 of the standard minimum achievement. While 6 students of 22 or $27 \%$ fail.

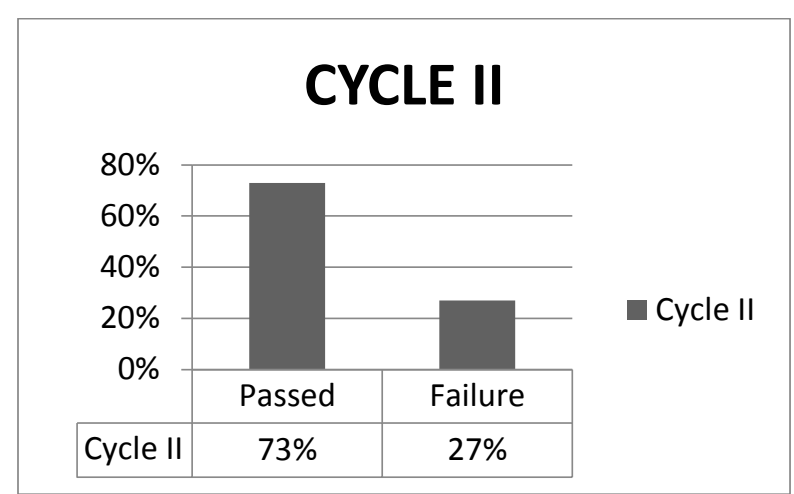

Figure 2. The Result of Students' Score in Cycle 2

Based on the Standard Minimum Achievement

Based on the result of cycle two above, it can be seen in Figure 2 that 16 students of 22 or $73 \%$ could reach 70 of the standard minimum achievement. While 6 students of 22 or $27 \%$ fail. It means they could not reach 70 of the standard minimum achievement. Percentage of the student passing in cycle two:

$$
\text { Percentage }=\frac{F}{N} \times 100 \% \rightarrow P=\frac{16}{22} \times 100 \%=73 \%
$$


There was a little increasing in their reading as far the tasks were given individually. In the second cycle the researcher found there the students will now reflect on their finding more accurately to define their material. This reflection would also include self-reflection by students. A few of the students reading score is increasing.

In cycle three that 22 of the students could reach 70 the standard minimum achievement, so they can improve their reading comprehension to $100 \%$ passed on KKM (70). The avarage score showed the significant improvement. It was 57,05 in cycle $1,73,18$ in cycle 2 , and 79,64 in cycle 3 . Therefore, the researchers think it is enough to prove that think pair share technique can improve students' reading comprehension.

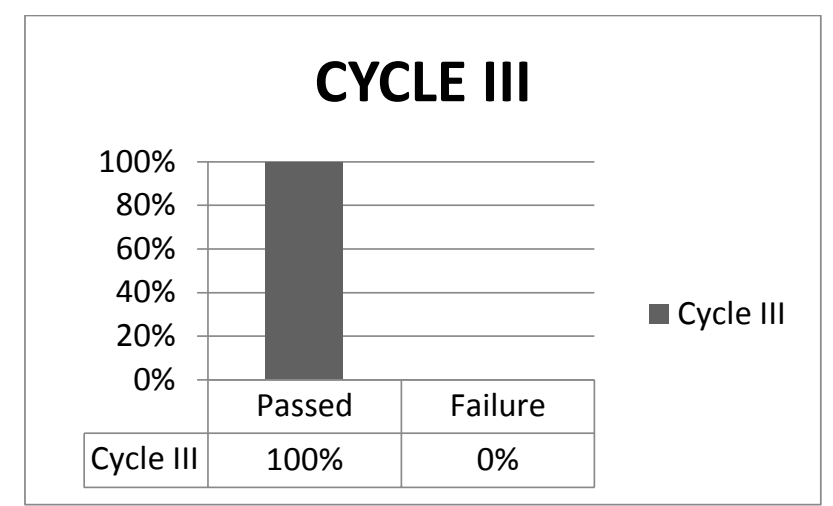

Figure 3. The Result of Students' Score in Cycle 3

Based on the Standard Minimum Achievement

In this cycle, the students pass $100 \%$ in minimal score (70) so it means the cycle is successful. The researchers stop this research until cycle III. Here is the percentage of the students who passing in the cycle three:

$$
\text { Percentage }=\frac{F}{N} \times 100 \% \rightarrow P=\frac{22}{22} \times 100 \%=100 \%
$$

There was interacting in their reading comprehension and the responses showed that they have good motivation in learning reading. Their motivations were high when the researcher used think pair share as a technique to increase and improve their reading comprehension.

\section{Discussion}

Based on the result, the researchers realize that by think pair share technique can improve students' reading comprehension. In cycle 1, the researchers find some students can not cooperate with their group because they seldom use this technique in group. Meanwhile, In cycle 2 students form their new group by themselves, with the new text, the researchers find some students active in share session, the almost all of students look supported in that learning. To get the fix data the researchers do cycle 3 to improve reading comprehension of students.

In cycle 3 , the researchers look the process of learning reading comprehension through think pair share technique is better than before about all of things. The 
improvement of reading comprehension through think pair share technique is significant.

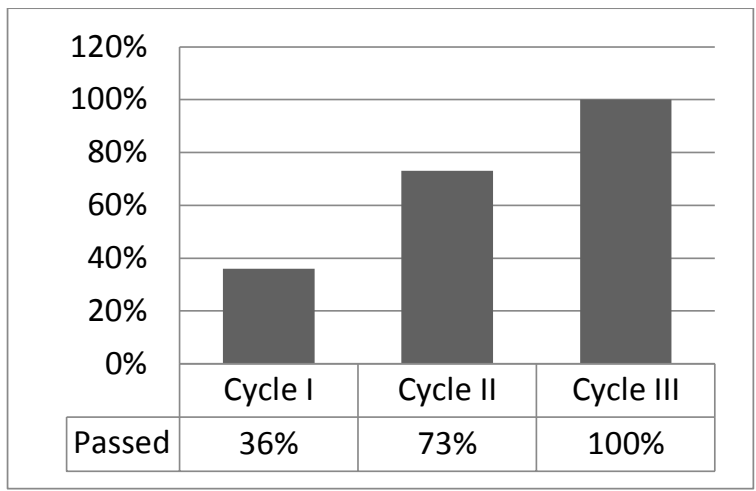

Figure 4. The Result of Students' Score in Cycle I, Cycle II and Cycle III

Based on the students' score chart above, the result of their test can be explained. Although a lot of the students have low motivation and also low support of their parents, but they still can improve their reading comprehension. It is shown by increasing score of their result of test.

The first bar's is the fisrt cycle of this research. The average scores of cycle one is $36 \%$ students passed on KKM (70). The average scores of cycle two is $73 \%$ students passed on KKM (70), it indicates there is an improvement in the students' achievement. The last,the scores of cycle three is $100 \%$ students passed on KKM (70), shown that is the best of the students' achievement.

The achievement could be more enhanced if using think pair share technique and it can be applied in daily teaching-learning process. However the time allotted for this research was not specially designed but taken from the time that was allotted for the four skills. Meanwhile, this research focused only one part of the skill. Thus, the cycle procedure could not be done out of the way from this teaching procedure.

There are some students who have low motivation in the following the kind of activities in learning English process. The students were confused to read, they also lazy to learn English because they lack of the knowledge and experience in English.

There are also some problems of the school itself, such as the lack of facilities needed to teach English in general, such as language laboratory and projector, and other facilities with high technology to support teaching English in the classroom. But at least the classroom action research has done, and the researcher conclude that teaching reading comprehension through think pair share technique can increase and improve students' reading comprehension, motivation, interests, attraction and also their score.

\section{CONCLUSION}

Based on the findings and discussion of research, it can be formulated some conclusions of through Think Pair Share technique in the learning teaching process can improve students' reading comprehension. Think Pair Share 
technique is a suitable technique to improve students' reading comprehension and it can increase the students' interest for learning English, especially reading comprehension. It can be seen from the students' scores increased in every cycle.

Based on the conclusions above, there are some suggestions adviced: 1) The teachers should increase the students' reading motivation in learning English by technique, like think pair share technique. Teachers have to try to apply the other technique in teaching learning process. Then, the teachers should be creative and choose a suitable technique in teaching learning process. They should upgrade themselves and adjust them into the new situation, by joining seminar, training, workshop etc. After that, the teachers should prepare many techniques to apply them to the students, not only giving explanation on the task, but also giving explanation through think pair share technique. It is very suitable for students. 2) The students should be more active in learning English. Because English is very important for their future. They should think that English is easy. Then students try to make more exercising and practicing in the daily life.They also must have a habit with using English in the daily life, it will be useful for students to increase their ability.

\section{REFERENCES}

ACT. (2013). Work Readiness Standards and Benchmarks. www.act.org

Ageasta, Y. M., \& Oktavia, W. (2018). Using The Think-Pair-Share Strategy in

Teaching Reading Narrative Text for Junior High School Students. Journal of English Language Teaching, 7(3), 497-505.

Anggraini, S. (2017). The Correlation between Reading Comprehension and Academic Achievement of English Education Study Program Students of UIN

Raden Fatah Palembang. (Publication No. 1099) [Diploma Thesis, UIN Raden Fatah Palembang]. Eprints Repository Software.

Arends, R. I. (2009) Learning to Teach. New York: Mc. Grow Hill Companies.

Brown, H. D. (2001) Teaching by Principle: An Interactive Approach to Language Pedagogy. New York : Longman.

Brown, H. D. (2004) Language Assessment Principle and Classroom Practice. New York: Longman.

Coiro, J. (2003). Reading Comprehension on the Internet: Expanding Our Understanding of Reading Comprehension to Encompass New Literacies. The Reading Teacher, 56(5), 458- 464.

Graham, L., \& Bellert, A. (2005). Reading comprehension difficulties experienced by students with learning disabilities. Australian Journal of Learning Difficulties, 10(2), 71-78..

Harmer, J. ( 2007). How to Teach English. London: Pearson Education Limited.

Heaton, J. B. (1975). Writing English Language Tests. New York: Longman.

Himmele, P. \& Himmele, W. (2011), Total Participation Technique: Making Every Student an active Learner. Alexandria, Virginia: ASCD.

Howard, V. (2011). The importance of pleasure reading in the lives of young teens: Self-identification, self-construction and self-awareness. Journal of Librarianship and Information Science, 43(1), 46-55.

Kagan, S., \& Kagan, M. (2009). Kagan Cooperative Learning. CA: Kagan Publishing. 
Maulida, F. (2017). The Use Of Think-Pair-Share in Teaching Reading Comprehension. In ELT Forum: Journal of English Language Teaching, 6(1), 49-58.

Nunan, D. (2003). Practical English Language Teaching. New York. McGrawHill.

Palupi, A. A., Suparman, U., \& Suka, R. G. (2013). Teaching Reading Comprehension Through Think-pair-share (TPS) Technique. U-JET, 2(7), 111.

Supriyani, P., Sudirman, S., \& Mahpul, M. (2017). The Use of Think Pair Share Technique to Improve Students Reading Comprehension in Report Text. $U$ JET, 6(8), 1-7.

Suryani, N. Y., \& Rifa'at, A. A. (2019). Improving Reading Comprehension Through Think-Pair-Share (TPS) Technique Students of STIK Siti Khadijah Palembang. ELT-Lectura, 6(1), 9-19. 